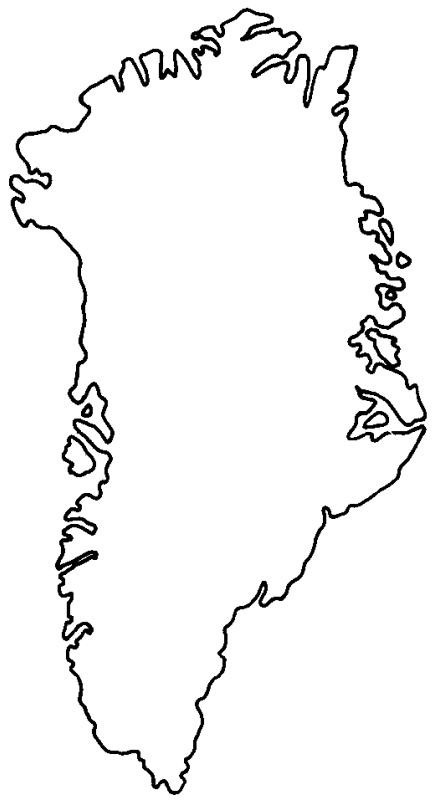

\title{
Present-day expansion of the southern part of the Inland Ice
}

\author{
Anker Weidick
}

In connection with the work on a West Greenland glacier atlas and glacier inventory the activity of a c. $1200 \mathrm{~km}$ long segment of the Inland Ice was investigated for the years 1950 and 1985 .

Around 1950 major parts of the ice margin were in a state of thinning and recession and exceptions were mainly confined to restricted highland areas where evidence of advance could be located. Updating of the conditions to 1985 reveals that marginal advances have now spread to parts of the adjoining lowland areas indicating a 'turn of the tide' where the general period of recession since last century to around 1950 is now substituted by a major tendency for advance.

A. W., Geological Survey of Greenland, Øster Voldgade 10, DK-1350 Copenhagen K, Denmark.

Registration of changes in the status of the Greenland ice cover on a routine basis is made at GGU and, apart from applied aspects related to technical activities such as mining and hydro-electric power, the observations contribute to the scientific investigation of glaciers in general, i.e. their response to climatic change. That glacier variations may be indicators of climatic change is generally realised, although the response of individual glaciers is dependent not only on climatic parameters such as temperature and precipitation, but also on local morphology and dynamic conditions.

Determination of actual glacier changes can also be used to verify deductive modelling of glacier variations with climatic change, and hence to improve modelling of future glacier/climate scenarios. However, in this context changes of the Inland Ice margin have mainly been related to long term climatic fluctuations (i.e. changes expressed in thousands of years or more) whereas local glacier variations have been related to short term fluctuations on the time scale of centuries or decades. The reason for this is easily understood. The recent history of local glaciers can be studied in detail together with the climatic and dynamic conditions governing them. However, because of the great size of the Inland Ice, there is a great range in regional and local dynamics, including lateral variations of the individual sectors, and contrasting conditions of sea and landbased parts of the margin; these factors veil the general trends of minor retreat or advance in the short-term fluctuations of the outlets.

\section{Documentation of glacier changes}

Information on marginal changes of the Inland Ice is most comprehensive for South and West Greenland between latitudes $59^{\circ} 30^{\prime} \mathrm{N}$ and $70^{\circ} \mathrm{N}$. Data include historical information from about 1850 onwards, aerial photographs since the 1930s (originals filed at Kort- og Matrikelstyrelsen, Denmark, formerly the Geodetic Institute) and scattered systematic measurements of a few glaciers.

All glaciers in West and South Greenland (local glaciers as well as those draining the Inland Ice margin) have been localised and described according to a reference system originally proposed by Müller et al. (1977) for an international glacier inventory; some simplification and alterations were made to the reference system for its application in Greenland. In this context the $c$. $1200 \mathrm{~km}$ long segment of the Inland Ice margin in South and West Greenland was divided into 267 sectors, each usually terminating in an outlet or lobe of the ice sheet.

Much of the information on the change of the individual glaciers in the Greenland inventory refers to the time around 1950, when complete aerial photographic coverage for South and West Greenland first became available. On the basis of studies of oblique and vertical aerial photographs areas of recession were classified by the distance between the active glacier front at that time and the outermost neoglacial moraines, or from the width of the trimline zone surrounding the glaciers. Stationary and advancing sectors were determined from 


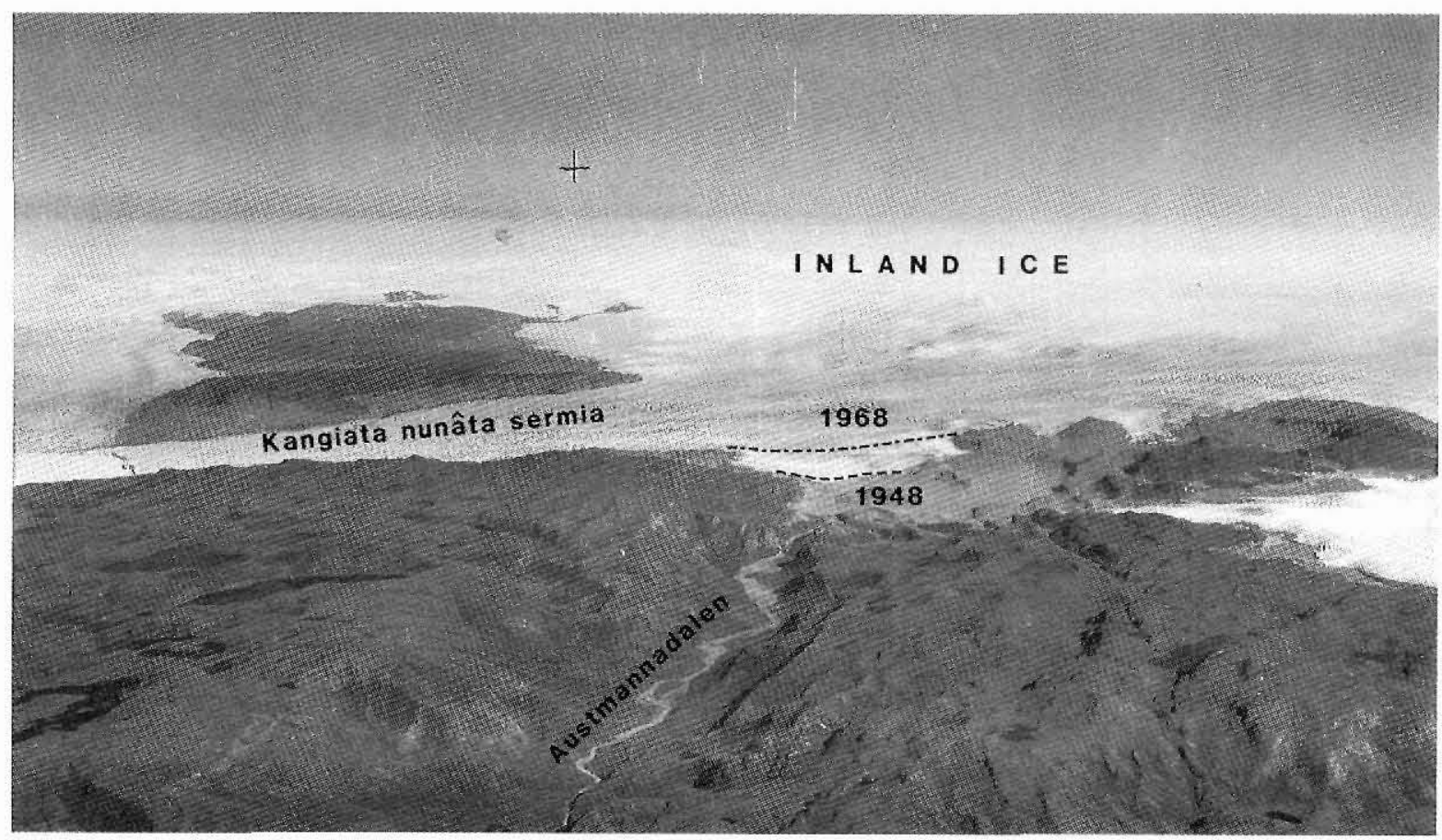

Fig. 1. Inner part of Godthabsfjord. Kangiata nunâta sermia is a tide-water glacier which has receded over $20 \mathrm{~km}$ since its maximum extent in the 18 th century. It is surrounded by a c. $300 \mathrm{~m}$ high trimline zone. The head of Austmannadalen was the end station for the first crossing of the Inland Ice in 1888 by Fridtjof Nansen. At that time the Inland Ice margin covered most of the ice margin lake. Its subsequent recession is shown by frontal positions in 1948 (date of photograph) and 1968 (dashed line). Copyright Kort- og Matrikelstyrelsen, Denmark. Route 505 D- $\varnothing$ no. 4627 of 20 th July 1948 . Reproduced with permission A. $200 / 87$

the absence of a trimline zone combined with absence or presence of morphological features such as push moraines or steep glacier fronts in the cases where no historical information was available.

The linear change of glacier fronts is not a complete reflection of a general thinning or thickening of glaciers. In places downwasting, or growth, of glaciers can be observed without any substantial change of frontal position. In the following description, however, glaciers showing these features are grouped respectively with the categories of 'receding' or 'advancing' glaciers.

It may be argued that the neoglacial maximum extent of glaciers of the individual sectors was not synchronous, and that subsequent oscillations prior to the recorded status about 1950 were not in phase but subject to local variations, dependent upon factors such as time lag of glacier response and morphology beneath and around the ice margin. However, historical documentation indicates that the major historical (neoglacial) maximum usually occurred in the middle or last half of the 19 th century and was followed by a general recession up to about 1950 (Fig. 2). It was only on the southern and south-western slopes of the Inland Ice (Fig. 3), around
Qagssimiut to Eqalorutsit kitdlit sermiat and at Kangiata nunâta sermia (Fig. 1) that the neoglacial maximum locally occurred earlier, presumably in the 18th century (Weidick, 1968). Examples of these 'exceptions' are illustrated in Fig. 2.

Net recession at sea level up to $c .1950$ is usually between $500 \mathrm{~m}$ and $2 \mathrm{~km}$ for land-based glaciers, and of the order of a few kilometres for the larger calf-ice producing outlets. Short term periodic changes of tidewater glaciers may be veiled by occasional major calvings and any changes should therefore be substantiated from trends of growth or thinning of the surrounding land-based ice margin. Furthermore, specific cyclic mechanisms unrelated to climate may occur in tidewater glaciers (Meier, 1987).

Exceptional major changes (first order fluctuations) characterise a few of the Inland Ice outlets of West Greenland (Eqalorutsit kitdlît sermiat, Kangiata nunâta sermia, Jakobshavn Isbræ, Upernavik Isstrøm). In Fig. 2 these are compared with first order fluctuations from outlets of local firn areas (Sermeq in South Greenland and Midgårdgletscher in East Greenland). All these examples are tide-water glaciers. However, apart from 


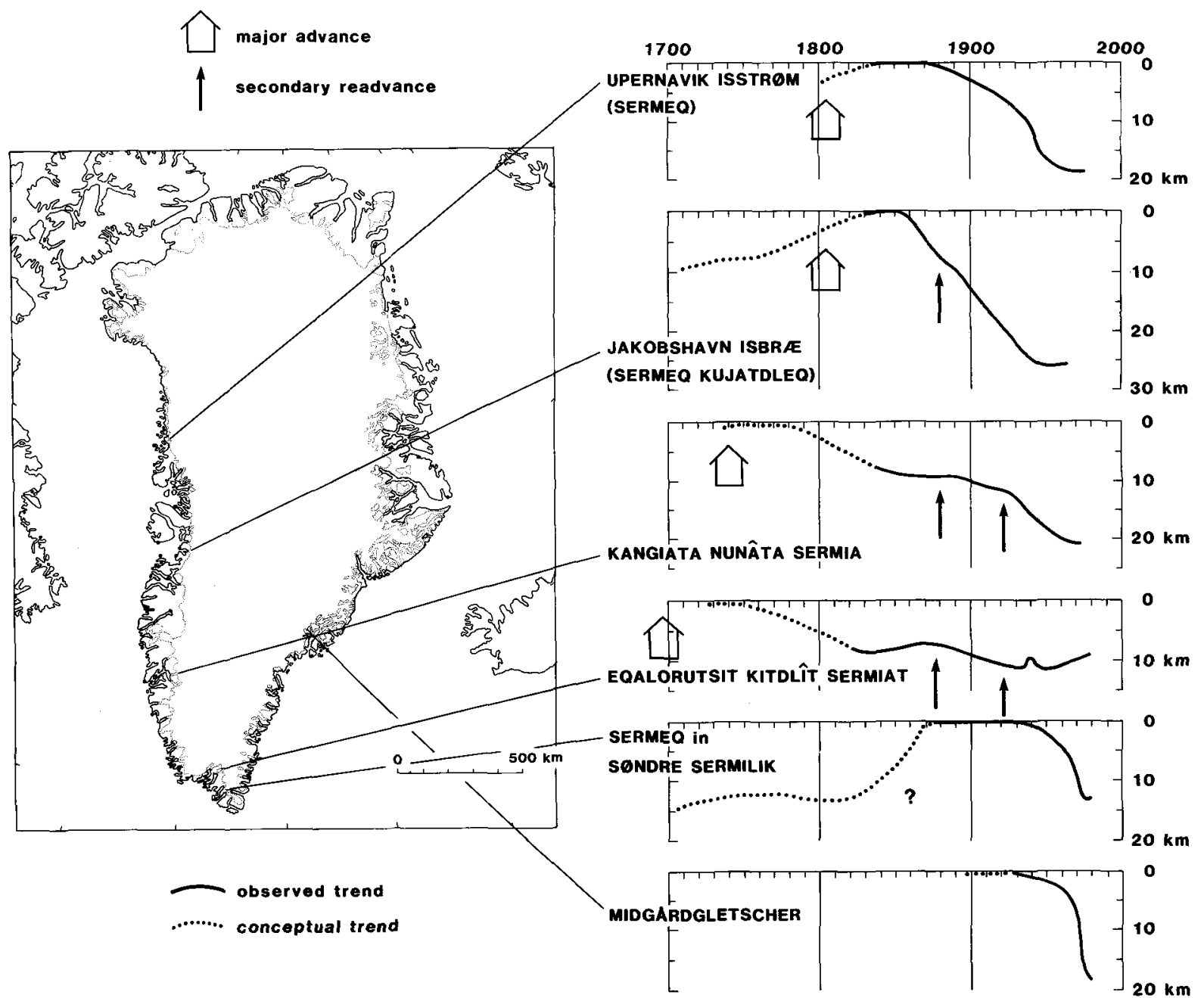

Fig. 2. Response curves of some major calf ice producing outlets from the Inland Ice (Upernavik Isstrøm, Jakobshavn Isbræ, Kangiata nunâta sermia, Eqalorutsit kitdlît sermiat) and other extensive ice covers (Sermeq in Søndre Sermilik and Midgårdgletscher near Angmagssalik).

exceptional net recessions of 12 to $25 \mathrm{~km}$, the curves of their frontal positions illustrate local variations in a general retreat, leading to the situation around 1950.

\section{Regional thinning pattern of the Inland Ice margin up to 1950}

A generalised interpretation of activity of the ice margin about 1950 is illustrated in Fig. 3. The width of the black zones gives an approximate indication of the intensity of recession (thinning) and advance (thickening).

Pronounced thinning is particularly evident in the Qagssimiut area, around Frederikshåb Isblink, at the head of Godthåbsfjord (Kangiata nunâta sermia) and around Jakobshavn Isbræ. The net thinning in these areas is estimated at up to $\mathbf{3 0 0}$ metres for the lowermost parts of the ice margin. Apart from the fact that extensive parts of the ice margin in these areas are situated close to sea level, they are also in the vicinity of the open sea or drain into extensive and wide fjord systems. The two southern regions (Qagssimiut and Frederikshåb Isblink) in a morphological sense approach conditions of piedmont lobes and have a lower apron part exposed to strong ablation. In three of the examples (Eqalorutsit kitdlit sermiat in the Qagssimiut area, Kangiata nunâta sermia in Godthåbsfjord and Jakobshavn Isbræ in Disko Bugt) the drainage of the ice margin is related to major drainage sectors of the Inland Ice and the glaciers have the status of ice streams. 


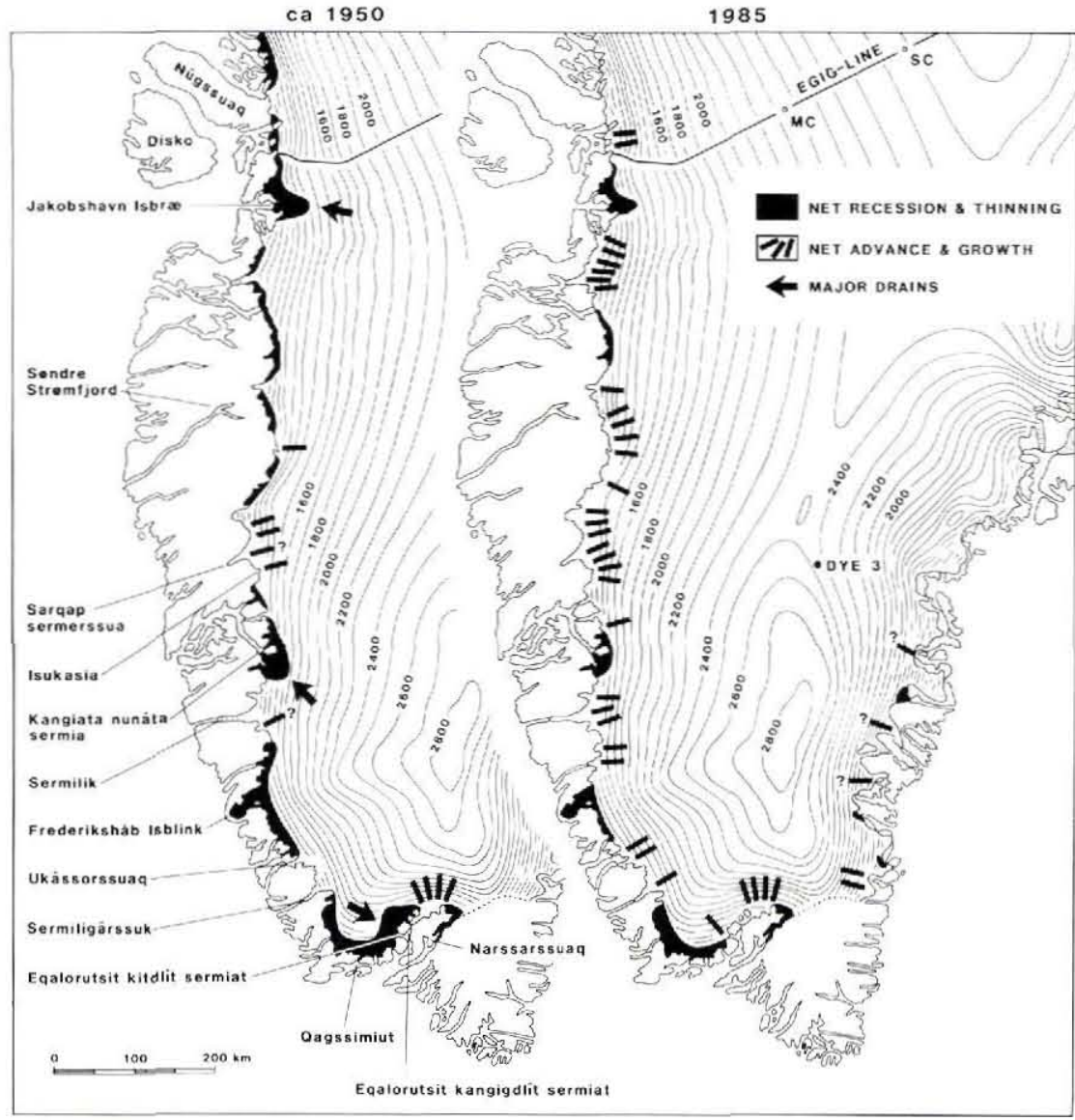

Fig. 3. Marginal activity in 1950 and 1985. Width of the black zone indicates the estimates of net thinning and recession. The trend of the western part of the EGIG-line is shown with the stations of Milcent (MC) and Station Centrale (SC). The position of the Dye 3 station is also indicated. Height contour lines according to Bindschadler ef al. 1989.

\section{Deviations from general recessional trends prior to 1950}

The proximity of these recessive areas to the sea, or to major fjord systems, could indicate the influence of strong ablation conditions related to greater convection than in the higher, more remote marginal areas of the Inland Ice. This speculation, however, cannot be documented from present investigations of mass balance, although local depressions of the glaciation limit in these regions could require consideration of specific ablation processes.

The extraordinary thinning and retreat of the three major drainage sectors (Fig. 3) is difficult to explain on the basis of the present knowledge of the subsurface and mechanics of tide-water glaciers. Other tide-water glaciers of much the same range of surface movement and calf-ice production only show frontal changes of a few kilometres. and marginal thinning of essentially less than $100 \mathrm{~m}$.
Variation in the topographical conditions beneath and around a glacier can cause disturbance in the general pattern of recession even at low altitudes. Thus, at calf-ice producing (tide-water) outlets in the fjords, Mercer's principle of locking front positions at widening of fjords has been stressed (Warren \& Hulton, 1990). Since this principle cannot be applied to all localities (e.g. Sermiligârssuk and Ukâssorssuaq) it is preferred to consider here the thinning around the glacier rather than to emphasise specific mechanisms.

Land-based fluctuations can also be influenced by local topography under the ice margin. An example from the Inland Ice margin south of Jakobshavn Isbrx has been described by Weidick (1968). The general thinning of the ice margin around Jakobshavn Isbræ has led to a change in the direction of ice flow so that ice formerly moving to Jakobshavn Isbre was diverted to areas south of this ice stream. The increase in ice flux to these areas was (and is) sufficient to compensate for the 
increased ablation of the present century, and has maintained a nearly stable ice margin throughout this period.

Areas of widespread stability or advance prior to 1950 are scarce (Fig. 3) and are mainly found in highland areas situated behind relatively wide stretches of land; around Eqalorutsit kangigdlit sermiat, possibly Sermiligârssuk and Ukâssorssuaq, Sermilik north of Frederikshåb Isblink, and in the Isukasia area north of Godthåbsfjord.

The major glacier outlets from these highland areas, Sermiligârssuk and Ukâssorssuaq (tide-water glaciers), Sermilik and Sarqap sermerssua (land-based outlets), also all show near-stability or advance in the period up to 1950 , in spite of their terminating at or near sea level. The glaciers are all 25 to $50 \mathrm{~km}$ in length with 4 to $6 \mathrm{~km}$ wide lobes, and occupy deep U-shaped valleys incised into the surrounding highlands.

It is difficult to assess the amount of advance for the ice margin in most of these highland areas, since historical information is sparse prior to the 1940s. However, it can be said that the ice margin of the southern area east of Eqalorutsit kidlît sermiat seems to have been steadily expanding throughout this century and there are indications that the same might be true for the Isukasia and Sarqap sermerssua areas.

\section{Readvance since 1950}

Readvance of remote higher parts of the ice margin was recorded for the area east of Eqalorutsit kidlit sermiat (Clement, 1983; Weidick, 1988) and around Isukasia (ACG Øresund, 1981).

Readvance of the ice margin in areas of earlier recession was first reported from the head of Godthåbsfjord (Knudsen \& Møller, 1982), and subsequently from the region around Eqalorutsit kitdlit sermiat (Weidick, 1984), the Søndre Strømfjord region (Scholz, 1987) and the area south of Jakobshavn Isbræ (Weidick et al., 1990).

However, in addition to the report of advances, areas with continuous retreat have been recorded around Frederikshåb Isblink (Weidick \& Thomsen, 1983), the inner part of Godthåbsfjord (Weidick, 1982; Weidick \& Thomsen, 1983) and areas north of Jakobshavn Isbræ (Thomsen et al., 1988).

This information has been supplemented with observations from a new series of 1985 aerial photographs covering all of West Greenland, and the general trends of changes for the Inland Ice margin of West Greenland between 1950 and 1985 are plotted on Fig. 3. A comparison of the conditions suggests that a 'turn of the tide' took place between 1950 and 1985, and that the zone of stagnancy or readvance is currently spreading from the highland Inland Ice margins to the lowland regions.

\section{Comparison with other evidence for recent growth of the Inland Ice}

Information from the southern coast of East Greenland is only available for tide-water outlets from the Inland Ice, and the changes in most places can only be assessed by comparison with frontal positions on the 1:250 000 topographical map sheets published by Kortog Matrikelstyrelsen, Denmark. These map sheets are essentially based on classical surveying in the 1930s. Comparison with Landsat scenes from the 1970s shows that the great majority of outlets are either stationary or show slight advance, and that recession is confined to a few areas. Most frontal changes are only of the order of a kilometre.

In Melville Bugt, North-West Greenland, the shelflike Inland Ice margin is anchored to skerries, but for the most part recent studies show there has been widespread continuous recession (P. R. Dawes, personal communication). A single example of this recession, shown in Fig. 2, is that of Upernavik Isstrøm.

A geodetic profile across the Greenland ice sheet made from Disko Bugt in West Greenland to Kong Oscar Fjord in East Greenland, the so-called 'EGIGline' (cf. Fig. 3), has been measured on several occasions. The lower western parts from 600 to $1200 \mathrm{~m}$ a.s.l. were surveyed in 1948 (Bauer et al., 1968), and the whole profile in 1959 and 1969 (Seckel, 1977). For the ablation area up to $1200 \mathrm{~m}$ a.s.l. a thinning of the ice sheet along the profile line of between 0.3 and $0.24 \mathrm{~m}$ ice $\mathrm{a}^{-1}$ (= annually) was determined, which is in general agreement with the measured decrease in thickness of the nearby Pâkitsoq area of $0.5 \mathrm{~m}$ ice $\mathrm{a}^{-1}$ between 1959 and 1985 for altitudes up to $500 \mathrm{~m}$ a.s.l. (Thomsen et al., 1988). In the accumulation area Seckel concluded there was an average increase in altitude along the profile line of $0.085 \mathrm{~m} \mathrm{a}^{-1}$, implying a thickening of the ice sheet. However, the reported increase of the altitude of this profile has been questioned by A. Ohmura (personal communication, 1990).

An independent assessment of surface elevations of the whole southern part of the Inland Ice based on satellite altimetry recorded an increase of $0.2-0.3 \mathrm{~m} \mathrm{a}^{-1}$ for the period 1978-1986 (Zwally et al., 1989). However, this result has been questioned by Douglas et al. (1990).

Accumulation trends since the culmination of the Little Ice Age (around A.D. 1600) determined from the records of ice cores in general show increased precipitation in warm periods, but in detail there is great variation (Reeh, 1983). Thus the trends of the Dye 3 and Milcent ice cores (location in Fig. 3) after 1600 are out of phase (Reeh et al., 1978), which appears to be related to the origin of precipitation (from the south- 
east at Dye 3, from the south-west at Milcent), and variations of sea ice which may have changed the general circulation pattern in the polar atmosphere (Reeh et al., 1978). This interpretation, however, was later modified (Reeh et al., 1985) since parts of the Dye 3 accumulation trends should be corrected for upstream flow in the ice sheet (Dye 3 is not situated on the ice divide). A general increase of accumulation over the southern part of the Inland Ice (i.e. expansion of the Inland Ice) since the Little Ice Age is therefore probable, but not yet fully substantiated.

\section{Interpretation of trends}

Theoretical calculation of the response of the Inland Ice margin to climate change since A.D. 600 in the area north of Jakobshavn Isbræ (Reeh, 1983) indicates that higher parts of the ice margin with their close proximity to the equilibrium line do not react with so great an amplitude to mass balance change as the lower parts, but will react faster. The equilibrium line where net ablation equals net accumulation is situated at $c .1500 \mathrm{~m}$ a.s.l. in South Greenland and c. $1200 \mathrm{~m}$ a.s.l. in central West Greenland.

This conclusion agrees with the fact that the trimline height (as a measure of net thinning) generally decreases with the altitude of the lobes, which explains the quasi-stability of the highland ice margins. However, it does not explain the apparent continuous advance of the ice margin in some of these highland areas.

The continuous advance may be connected with a balance of the ice margin at high altitudes which reflects long term changes in the accumulation of the interior ice sheet with a time lag of centuries, rather than the present temperature changes which govern the mass balance of the lower parts of the ice margin. The advance of the highland glacier lobes is not necessarily related to a general increase in accumulation in the accumulation areas. The present map of distribution of accumulation on the Inland Ice refers to a situation around 1950, and this distribution may have changed significantly with time (e.g. during the Little Ice Age some hundred years ago). However, no investigations on such spatial variations with time have been made so far.

The general spread of advance to the lowland ice margins since 1950 has still left some relict areas of recession, especially around the major drainage streams of Kangiata nunâta sermia and Jakobshavn Isbræ, but future readvance may be expected also to occur in these regions.

Thus the response of the major ice streams of Kangiata nunâta sermia and Jakobshavn Isbræ lags behind the rest of the ice margin and appears to contradict the historical records of early or contemporaneous attainment of the maximum extent in historical time for these outlets. However, while historical records and geological dating can indicate the attainment of the maximum extension of the ice in the 18th and 19th century, they do not show the build-up of the ice marginal areas prior to such an advance.

If this picture of events is valid, it is the first time that there has been a possibility of following the build-up of a continental ice sheet margin in detail, and detailed investigations on future changes of the major drainage streams may shed new light on mechanisms of stability or instability around the great tide-water glaciers, their relationships to the surrounding ice masses and the climatic changes which are the primary cause of these changes.

\section{References}

ACG/Øresund 1981: Isukasia iron ore mine field investigations 1981. - Report on movement of glaciers and ice surface elevations. Internal report from Arctic Consultant Group to the Cryolite Company Øresund, $10 \mathrm{pp}$.

Bauer, A., Ambach, W. \& Schimpp, O. 1968: Movement et variation d'altitude de zone d'ablation ouest de l'Inland du Groenland entre 1948 et 1959. Meddr Grønland 174(1), 79 pp.

Bindschadler, R. A., Zwally, H. J., Meyer, J. A. \& Brenner, A. C. 1989: Surface topography of the Greenland Ice Sheet from satellite radar altimetry. NASA SP-503, $105 \mathrm{pp}$.

Clement, P. 1983: Glacial-hydrologiske forhold i Nordbosøbassinet, Johan Dahl Land. Grønlands geol. Unders. Gletscherhydrol. Meddr 83/9, 54 pp.

Douglas, B. C., Cheney, R. E., Miller, L., Agreen, R. W., Carter, W. E. \& Robertson, D. S. 1990. Greenland ice sheet: is it growing or shrinking? Science 248, 288 only.

Knudsen, N. T. \& Møller, J. T. 1982: Photogrammetric survey of Qamanârssup sermia. In Andreasen, J. O., Knudsen, N. T. \& Møller, J. T.: Glaciological investigations at Qamanârssup sermia. Field report 1980. Grønlands geol. Unders. Gletscher-hydrol. Meddr 82/4, $26 \mathrm{pp}$.

Meier, M. F. 1987: Fast tidewater glaciers. J. geophys. Res. 92, B9, 9051-9058.

Müller, F., Caflisch, T. \& Müller, G. 1977: Instructions for compilation and assemblage of data for a world glacier inventory, $19 \mathrm{pp}$. Zürich: Temporary Technical Secretariat for the World Glacier Inventory.

Reeh, N. 1983: Ikke-stationær beregningsmodel for Indlandsisens randzone. Gronlands geol. Unders. Gletscher-hydrol. Meddr 83/7, $81 \mathrm{pp}$

Reeh, N., Clausen, H. B., Dansgaard, W., Gundestrup, N., Hammer, C. U. \& Johnsen, S. J. 1978: Secular trends of accumulation rates of three Greenland stations. J. Glaciol. 20, 27-30.

Reeh, N., Johnsen, S. J. \& Dahl-Jensen, D. 1985: Dating the Dye 3 deep ice core by flow model calculations. In Langway, 
C. C., Jr., Oeschger, H. \& Dansgaard, W. (ed.) Greenland ice core: geophysics, geochemistry \& the environment. Geophys. Monogr. Am. geophys. Un. 33, 57-65.

Scholz, H. 1987: Expeditionsbericht Westgrönland 1986/87. Beiträge zur Geologie und Botanik der eisrandnahe Gebiete in der Umgebung des Örkendals westlich von Söndre Strömfjord, Westgrönland, 87 pp. (Abschlussbericht zum DFGProjekt 'Aktuogeologie' in Westgrönland, Antrag II C G Scho 277/2-1 von 9.10.1985).

Seckel, H. 1977: Höhenänderungen im Grönländischen Inlandeis zwischen 1959 und 1968. Meddr Grønland 187(4), 58 pp.

Thomsen, H. H., Thorning, L. \& Braithwaite, R. J. 1988: Glacier-hydrological conditions on the Inland Ice northeast of Jakobshavn/llulissat, West Greenland. Rapp. Grønlands geol. Unders. 138, map sheet.

Warren, C. R. \& Hulton, N. R. J. 1990: Topographic and glaciological controls on Holocene ice-sheet margin dynamics, central West Greenland. Ann. Glaciol. 14, 307-310.

Weidick, A. 1968: Observations on some Holocene glacier fluctuations in West Greenland. Meddr Gronland 165(6), 202 pp. (also Bull. Grønlands geol. Unders. 78).

Weidick, A. 1982: Klima- og gletscherændringer i det sydlige Vestgrønland $\mathrm{i}$ de sidste 1000 år. Grønland 1982, 235-251.

Weidick, A. 1984: Location of two glacier surges in West Greenland. Rapp. Grønlands geol. Unders. 120, 100-104.

Weidick, A. 1988: Gletschere i Sydgrønland. Geologi $i$ Grønland 2, $80 \mathrm{pp}$. København: Grønlands Geologiske Undersøgelse.

Weidick, A. \& Thomsen, H. H. 1983: Glaciologiske undersøgelser Frederikshåb/Pâmiut 1982. Grønlands geol. Unders. Gletscher-hydrol. Meddr 83/6, 46 pp.

Weidick, A., Oerter, H., Reeh, N., Thomsen, H. H. \& Thorning, L. 1990: The recession of the Inland Ice margin during the Holocene climatic optimum in the Jakobshavn Isfjord area of West Greenland. Palaeogeogr. Palaeoclimat. Palaeoecol. (Global planet. Change Sect.) 82, 389-399.

Zwally, H. J., Brenner, A. C., Major, J. A., Bindschadler, R. A. \& Marsh, J. G. 1989: Growth of the Greenland Ice Sheet: measurements and interpretation. Science 246, 1587-1591. 